\title{
Investigating rural community behaviour after the 2004 Chuetsu earthquake: a case study of Kawaguchi town, Japan
}

\section{Gismondi}

Asia Air Survey Co., LTD, Shinyuri 21 bldg., 2-2 Manpukuji-1, Asao-Ku, Kawasaki City, Kanagawa, 215-0004, Japan

Received: 8 August 2011 - Accepted: 14 October 2011 - Published: 6 December 2011

Correspondence to: M. Gismondi (mto.gismondi@ajiko.co.jp)

Published by Copernicus Publications.

Investigating rural

community behaviour

after the 2004

Chuetsu earthquake

M. Gismondi

Title Page

Abstract

Introduction

Conclusions

References

Tables

Figures

14

$\rightarrow \mathbf{I}$

4

Back

$\checkmark$

\section{Full Screen / Esc}

Printer-friendly Version

Interactive Discussion 


\section{Abstract}

Every year, earthquakes cause economic and human losses around the globe. In Japan, a great deal of attention has focused on improving the safety of structures and individuals in the last decade. The introduction here of several new related policies,

5 together with continuous discussion of such policies, has raised the level of environmental security nationwide. Despite this significant effort, individual preparedness and awareness are still lacking, especially in rural areas, where technological advancements and policy applications often arrive late. In this paper, Kawaguchi town in Niigata Prefecture, Japan was chosen as study area because of both the major damage 10 experienced during the 2004 Chuetsu earthquake and the particularly dynamic sociocultural activities of the community. Using interviews and questionnaires to collect information, this study aims to investigate the causes of local variations in community behaviour after the earthquake. Geographic location as well as everyday social relationships, social interactions and organisation are considered the main causes of the 15 differences in community organisation during the recovery process. This study highlights the necessity for more localised emergency education in order to promote longer lasting awareness and preparation in rural areas.

\section{Introduction}

Globally rural and urban communities experience natural disasters such as floods, tropical cyclones, earthquakes and drought (Burton et al., 1993). More so than the other types, an earthquake is an "event that can be prepared for in advance" (Turner, 1976). In areas at high risk for earthquakes, community preparation, including emergency provisioning, emergency communication plans and community-based planning, is therefore crucial (USGS, 2005; FEMA, 2006). Despite the common, worldwide occurrence of natural disasters, in the last three decades, their definition and characteristics have been the topics of a considerable amount of discussion (Hewitt, 1983; Dynes, 1993).
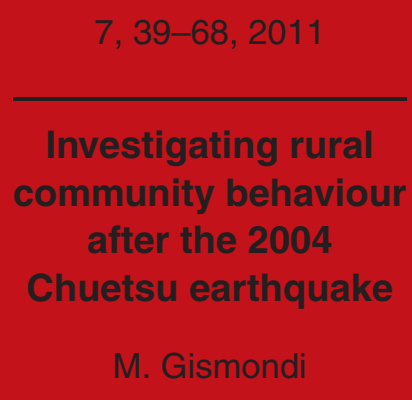

Title Page

Abstract

Conclusions

Tables

14

4

Back

Full Screen / Esc

Printer-friendly Version

Interactive Discussion 
Although earthquake engineering research and hazard mitigation has advanced in recent years, the pace of economic development and urbanisation has increased the risk from earthquakes and resulted in exposing more of the world's population to earthquakes (Tucker et al., 1994). Japan experienced approximately 18 percent of the total 5 number of earthquakes globally of magnitude 7 and above between 1997 and 2006 (OECD, 2009). The Japanese population has subsequently learned to survive in a high seismic risk environment and adopted measures to minimise the damage produced by seismic events, and to improve the recovery process (Usami, 1979). The Japanese government has developed several national policies within the last $50 \mathrm{yr}$ to 10 address such events, such as the Disaster Relief Act (1947), the Countermeasures Basic Act (1961) and the Earthquake Disaster Management Special Measure Act (1995). These policies focus on decentralising and localising emergency operations in disasters. Recently, the Central Disaster Management Council (CDMC) established an Earthquake Disaster Management Reduction scheme, putting into place new disas15 ter mitigation goals and refining policies on earthquake-resistant housing and public facilities (Suganuma, 2006). Despite the progressive and continuous improvement of these policy frameworks, the roles and responsibilities of organisations and individuals during and after an earthquake remain unclear; moreover, the exchange of information among different levels of government is still insufficient (OECD, 2009).

Despite the efforts of the Japanese government, there are notable differences between metropolitan and rural areas that further complicate the successful adoption of the policies previously described. In conceptual as well as practical terms, urban and rural areas present some of the most significant sources of regional variation. In fact, many studies have noted that individualism and collectivism are often coincident with modern (urban) and traditional (rural) social conditions, respectively (Kagitçibasi, 1997; Kashima, 2001; Oyserman et al., 2002). The regional differences between urban and rural areas are, therefore, representative of different lifestyles and traditions (Gismondi, 2010). Under a modern, urbanised social order, an individualistic lifestyle is most common and limits the degree of collectivism apparent in society (Triandis,

\section{SGD}

邹

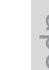

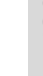

\section{西}


1995). Alternatively, under a traditional, rural social order, people are more prone to adopt a collective lifestyle. In rural areas, diverse but interlocking social roles, including different types of occupations such as agricultural activities and services for the local community, all serve to maintain a collective lifestyle (Baumeister, 1986 and 1987). 5 Differences in lifestyles may contribute to a resident's behaviour and may shape his or her response in the case of a seismic event, especially in areas in which urban and rural lifestyles coexist. Due to economic and political interests, urban areas benefit from policies and technological improvements aimed at preventing damage from earthquakes; remote areas are more vulnerable, however, due to the lack of awareness, 10 policies, earthquake-resistant construction and anti-seismic evaluations (Matsushita et al., 2008).

Vulnerability can be defined as "the characteristics of a person or group and their situation that influence their capacity to anticipate, cope with, resist and recover from the impact of a natural hazard" (Wisner et al., 2004). Another definition incorporates 15 the concept of "capacity" as the ability of a group or household to resist the violence of a hazard and easily initiate the recovery process (Anderson and Woodrow, 1998; Wisner, 2003). Both these definitions include the concept of disaster defined by Fritz (1961:665) in the context of social science: "An event, concentrated in time and space, in which a society undergoes severe danger and incurs such losses to its members and 20 physical appurtenances that the social structure is disrupted". When assessing vulnerability, it is essential first to define the type of disaster. According to Wisner et al. (2004), the following four factors determine earthquake vulnerability: location of the epicentre, damage produced, temporal characteristics, and building characteristics. The epicentre and damage caused by past earthquakes provide preliminary information about a 25 region's seismic susceptibility. The temporal characteristics of an earthquake produce extensive information about the frequency of earthquake events and can inform the level of risk awareness. For example, an earthquake occurring at night would produce higher numbers of casualties because people in their homes would be more exposed to injuries (Alexander, 1985). Given that over 95 percent of all deaths in earthquakes

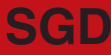

(3)

政

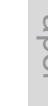

$\frac{0}{2}$

\section{西}


are caused by the collapse of buildings (Alexander, 1985), building characteristics, including the level of structural safety and anti-seismic construction measures, play a significant role in determining vulnerability (Cuny, 1983; Coburn and Spence, 2002). On the policy level, the protective measures responding to these issues include struc5 tural and non-structural regulations and other preventive policies. After an earthquake, relief measures, such as the availability of provisions and medical accessibility are critical factors in reducing the vulnerability of human populations (WHO, 1997).

Understanding the vulnerability of communities who live in areas at risk of earthquakes is the first step in implementing preparative measures (Tierney, 2001). More10 over, the introduction of Geographic Information Systems (GIS) as a support tool has enabled the analysis of a great deal of information about seismic hazard risks (King and Kiremidjan, 1994; FEMA, 2001), disaster management (Mansourian, 2005; Saadarseresht, 2006) and post-earthquake support measures (ESRI, 2007; EMC, 2007). Although a wide range of studies in disaster reduction have been reported, 15 the responsibility for successfully organising to minimise the impact of a natural hazard falls to the different institutional levels (Tierney, 2001). Despite progress in our understanding of vulnerability to earthquakes, the institutions responsible for raising awareness, ensuring individual preparedness and increasing investment in preventive actions have not yet exercised their full capacity for action (Adger, 2006). In the last decade, several global programs have been developed to improve earthquake safety, including prominent initiatives such as the Community Emergency Preparedness (WHO, 1999) and the Global Earthquake Safety Initiative (GeoHazard International United Nations Centre for Regional Development, 2001). The priority of these studies is to reduce earthquake risk by providing short- and long-term emergency preparedness programs, combining the findings of scientific research on natural hazards with governmental policy planning (WHO, 1999; UNCRD, 2001). An emergency preparedness program should also take in account factors such as geographical location and accessibility. Indeed, if an earthquake occurs, remote areas would have higher possibility of remaining isolated due to their inaccessibility, especially when they are located in mountainous

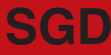

东

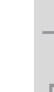

西


areas (Olshansky et al., 2006). In these circumstances, the local community becomes an important provider of support during the recovery process. For the purposes of this study, the "community" is defined as a group of people living in the same area and interacting socially. Despite living in similar environmental conditions, discrepan-

5 cies and problems can arise among members of a given community in the case of an emergency. Raising awareness and preparing to face an earthquake is the first step that a community takes toward its independence (Coburn and Spence, 2002), even though maintaining a sufficient level of awareness and organisation is arduous and requires continuing efforts (Smith, 1961; Yoshida, 1964; Coburn and Spence, 2002). The 10 Japanese Cabinet Office Survey on Disaster Preparedness has confirmed a decrease in the public awareness of risk after a major earthquake (Suganuma, 2006). The actual policy system does not sufficiently provide the preparation required to face a seismic event in rural areas (OECD, 2009).

While much research has been done on the vulnerability and resilience of commu15 nities, few studies have been carried out on how rural communities respond to natural disasters such as earthquakes in Japan. Therefore, this study aims to understand the causes behind the differences in rural community behaviour after an earthquake and how the characteristics of a community can be used to promote awareness and preparation. A bottom-up methodological approach, based on fieldwork and multiple 20 interviews, was proposed in this study to summarise and interpret how the community reacted after the earthquake. Understanding the regional character of the community organisation and behaviour evident in the town's residents may be the key to raise awareness and improve the preparation of safety procedures for future earthquakes.

\section{Kawaguchi town and the Chuetsu earthquake}

25 Kawaguchi town is located at the bottom of a wide valley in a hilly area surrounded by mountains, inland of the Niigata Prefecture in the Chuetsu area, $25 \mathrm{~km}$ from the city of Nagaoka. The term "town" here designates an administrative spatial unit, not an urban
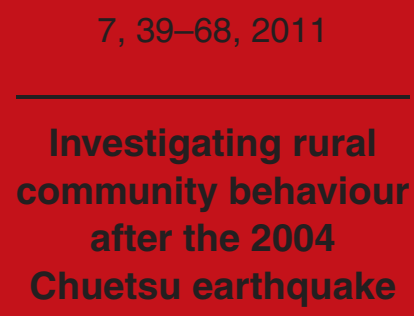

Title Page

Abstract Introduction

Conclusions References

Tables Figures

$1<$

4

Back Close

Full Screen / Esc

Printer-friendly Version

Interactive Discussion 
settlement, and in this case the district of Kawaguchi town actually includes rural and remote, as well as an urban, locations. The district is situated between $37^{\circ} 10^{\prime} 12^{\prime \prime}$ to $37^{\circ} 18^{\prime} 58^{\prime \prime} \mathrm{N}$ and $138^{\circ} 49^{\prime} 57^{\prime \prime}$ to $138^{\circ} 51^{\prime} 44^{\prime \prime} \mathrm{E}$ (Fig. 1). On 31 March 2010 , Kawaguchi was absorbed into the city of Nagaoka through the dissolution of the Kitauonuma dis5 trict. The town had 5572 residents in 2004 and a population density of 111 persons per $\mathrm{km}^{2}$ (Research Group on Damage of Mid-Niigata Earthquake, 2005). Similar to most rural regions in Japan, the population is progressively declining due to migration, and consequently, the percentage of the population represented by elderly individuals continues to increase (Gee, 2000). Local small businesses and agricultural activities 10 make up the economy in the region. The area receives heavy snow during the winter and is affected by landslides in the spring because of the geological conditions of differential denudation, which is a recurrent phenomena around Kawaguchi (Konagai, 2004). The Niigata Prefecture is historically a high seismic area. Three notable recent earthquakes occurred in the last $50 \mathrm{yr}$ provoking high damages to the prefecture: the 1519647.5 magnitude quake close to Niigata city, the 2004 Chuetsu earthquake and the 2007 Chuetsu offshore earthquake. Despite the numerous earthquakes recorded in history, the current policy system on anti seismic construction and awareness raising is arguably still not mature enough in this overall district (OECD, 2009).

The Chuetsu earthquake occurred Saturday, 23 October 2004, and produced a 6.6 20 surface wave magnitude, a 7 magnitude on the Japanese Meteorological Agency seismic intensity scale (JMA scale) and an estimated economic cost of 30 billion USD (Munich, 2005). The Chuetsu earthquake was the most expensive earthquake in Japan after the Kobe earthquake (1995). Kawaguchi reported heavy damage to its buildings and its communication network and was isolated for three days (Research Group on Damage of Mid-Niigata Earthquake, 2005). The prominent aftershocks that were recorded (Fig. 2) caused further damage and hindered rescue activities (Hirata et al., 2005). Three areas, namely a central site, a peripheral site and an isolated site were chosen to observe community behavioural patterns and compare behaviours occurring during the recovery process within Kawaguchi (Fig. 1) (Gismondi and Huisman, 2011).

\section{SGD}

西

(D)

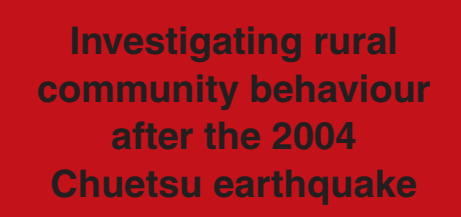


The division into central, peripheral and isolated locations follows the typical structure used by urban planners to define different areas of a city (Lynch, 1960).

\section{The interview process}

This study used face-to-face interviews and questionnaires to collect detailed informa5 tion about the behaviour of households and local communities, a method that allowed an efficient data collection and the sharing of information. In previous studies, such as those of such as Kimura et al. (1999) and (2001), a questionnaire was submitted to a selected number of people in a specific area through the postal service, with arrangements made to receive answers in the same manner. Although this method 10 simplifies planning, it collects answers without obtaining any further information about the respondent's background and behaviour. Each household was considered as the unit of reference for the interview. In total, 58 complete household interviews were conducted. That is 21 household in the central area, 16 in the peripheral area, 13 in the isolated area, and 8 households which moved inside the study areas after the 15 earthquake from more remote areas of the town (Gismondi and Huisman, 2011). In this study it is assumed that the centre of Kawaguchi town will retain aspects of a urban lifestyle, whereas more isolated areas will show a predominantly traditional way of living, following the studies undertaken by Kagitçibasi (1997), Kashima (2001) and Oyserman et al. (2002). For this reason, three sample areas were selected in order to 20 reproduce a social reality capable of representing the whole town and its varying component social relations and social structures. The assumptions previously cited do risk essentialising the respective constucts of rural/traditional and urban/modern, but they are nonetheless believed to be useful concepts for distinguishing between two different lifestyles following the objective proposed in this paper.

The interviews covered the following topics: the geographic location of a household's house, details about daily household and social activities before the earthquake, community activities and the participation of the respondents in those activities, the level
SGD
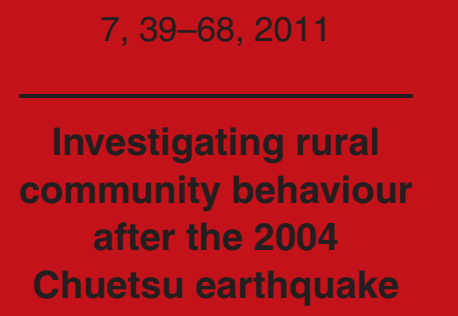

Title Page

Abstract

Introduction

Conclusions

References

Tables

Figures

14

$>1$

4

Back

$\checkmark$

Full Screen / Esc

Printer-friendly Version

Interactive Discussion 
of preparation and awareness before the earthquake, and the observed changes in behaviour after the earthquake (as shown in Table 1). At the end of each interview, a short questionnaire was distributed to collect further information, including the amount of damage experienced, the respondent's behaviour during the evacuation, and any 5 support given or received. The three study areas were compared using the information collected through the interviews and questionnaires. The comparison focused primarily on the structural damage caused by the earthquake and the community support and communication during the recovery process to illustrate important factors in vulnerability reduction and risk analysis (Kimura et al., 1999 and 2007).

\section{Results}

\subsection{Characteristics of the research areas}

Table 2 highlights the main attributes of the residents that characterise the three study areas totalling 1863 individuals out of the 5572 of the whole Kawaguchi town. The central area, or core of the town, is composed of six communities (or neighbourhoods) with a total of 432 households with a resident age averaging $45 \mathrm{yr}$, and its inhabitants work primarily in local businesses within or outside the central area. Public transportation and the main shops, restaurants and governmental buildings are located in this zone. The earthquake disrupted the road network and prohibited rescuers from reaching the town until three days after the first tremor. Despite the large number of households, the local communities here did not prepare any emergency evacuation plan or shelter assignments. The area contains a large number of individuals per household, a characteristic that used to be common, especially after the end of the Second World War, which often include several generations living in the same house. Additionally, younger individuals and newcomers from other villages populate the area.

\section{SGD}
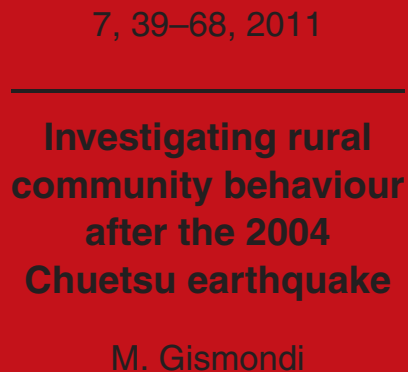

Title Page

Abstract

Conclusions

Tables

14

4

Back

Full Screen / Esc

Printer-friendly Version

Interactive Discussion 
The peripheral area is smaller in size and comprises 80 households and two communities, with residents reporting an average age of $57 \mathrm{yr}$. Despite being less than $1 \mathrm{~km}$ away from the central area, agricultural activities dominate the landscape, leaving more free space between households for interactions and thereby encouraging neigh5 bourhood relationships. The only bridge connecting the peripheral to the central zone was damaged during the earthquake, further isolating this area over the subsequent three days. A family structure similar to that observed in the central area was recorded in the peripheral zone.

The isolated area consists of a single community of 52 households located in the 10 hills $8 \mathrm{~km}$ northeast of the city centre. The residents in this area reported the highest average age of $64 \mathrm{yr}$, and the main labour activity was found to be the cultivation of rice and vegetables. No public transportation is available in this area, and the local school lies unused due to the absence of children in the community. Nevertheless, the local school is often used for local events and as a shelter in the case of natural disasters or emergencies. The relatively small number of community members and their agricultural activities were found to have positively influenced the relationships between members in this study area. Because of the distance from the central zone and the damage caused by the earthquake, this community experienced the longest isolation, extending up to five days. The position of the village on a hillside induced a

large number of landslides and explained the longer isolation time due to greater efforts required by the rescuers to re-establish the main commuting road.

\subsection{Damage experienced and evacuation methods}

The 2004 Chuetsu earthquake produced strong ground movements and ultimately caused considerable damage. Six people were killed; 62 were injured; 606 houses 25 were completely destroyed; 146 houses were seriously damaged; and 641 houses were moderately damaged. Public facilities were also affected. Figure 3 shows two example of the damage produced by the earthquake and the same area at the end of the recovery process. In the city centre, the compact urban structure and nucleated

\section{SGD}
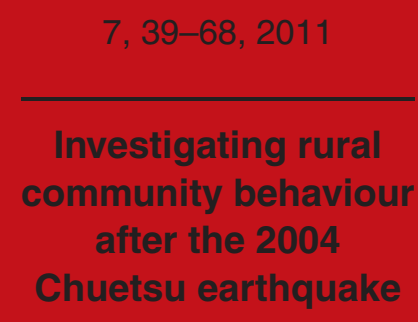

Title Page

Abstract

Introduction

Conclusions

References

Tables

Figures

14

$\Delta$

4

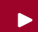

Back

Close

Full Screen / Esc

Printer-friendly Version

Interactive Discussion 
housing pattern exacerbated the negative impacts of the earthquake because the houses that were damaged first collapsed and affected the surrounding buildings. Antiseismic structures were mainly present in public buildings, but private housing structures had been constructed mainly out of wood. Despite its proximity to the city centre, 5 only minor damage to infrastructure was recorded in the peripheral area. The reduced amount of damage was the reason that the houses in the peripheral study area needed only reinforcement and refurbishment, whereas those in the central area needed to be completely rebuilt. The reduced damage positively influenced the recovery process and enabled faster rehabilitation and reconstruction after the earthquake. The isolated 10 area presented a similar distribution of damage as was observed in the central area, such that less durable wooden construction amplified the damage to housing. Additionally, road deterioration and landslides were reported in the hills surrounding the isolated area. Despite the greater amount of damage, refurbishment and consolidation of the houses were also considered in this area rather than complete reconstruction.

15 Local government officers stated during the interview: "Although we knew about the high seismic risk of the region, we did not organise emergency procedures in case of earthquakes. Therefore when the first shake occurred panic spread in Kawaguchi with a good portion of the town residents trying to reach the local government buildings seeking support". The lack of preparation and awareness contributed to the fear and panic that were reported as the most common reactions to the earthquake and resulted in individuals rarely moving to a place of refuge inside homes during the seismic event. In the central area after the earthquake, the evacuation pattern was disorganised. The dense urban structural fabric, combined with the lack of preparedness, forced individuals from different communities to mix and group together in the few remaining open 25 places, such as parking areas and temple courtyards. Due to the severity of the damage and the fear of profiteering, most of the residents used their own cars as provisional shelter for the first several days of the recovery process. An example is the witness of a $62 \mathrm{yr}$ old victim "we lived in our car for one week, we were too afraid to sleep inside the house". When the residents' focus shifted from their individual houses, they began

\section{SGD}

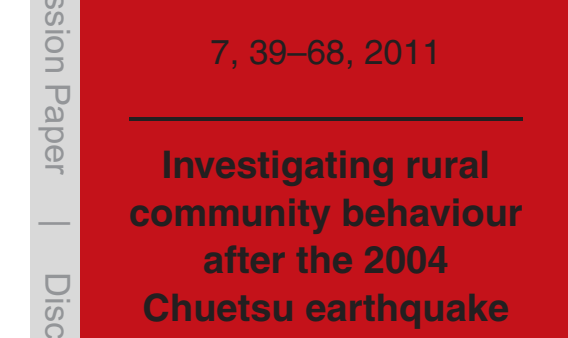

Title Page

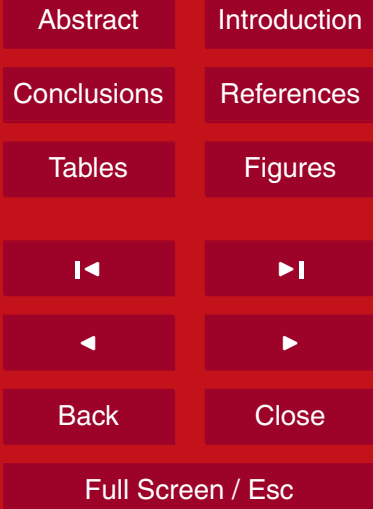

Printer-friendly Version

Interactive Discussion 
community organisation within the area. The observed lack of knowledge about town shelters provides another example of the difficulties of organising the community immediately after the earthquake. Residents generally moved to the closest shelter or close to the local government building. Although a portion of the population began to 5 move to official public shelters, the local government has confirmed the total absence of household sheltering: "residents did not know where to go, this was the main reason of the panic which spread immediately after the earthquake".

The reactions in the peripheral area were similar to those observed in the central zone, including the primary importance of individuals providing protection to their own 10 families inside their houses. However, the lower density of the urban structure in this area provoked a scattered evacuation pattern, contrary to the concentrated evacuation patterns observed in the central area. Residents here also preferred their cars as provisional shelter for the first night following the earthquake, once again indicating the attachment of the respondents to their own houses and the fear of robbery. As stated by 15 one of the victims: "I was afraid, my house collapsed and I did not want to move. I kept living in my car until the rescuers arrived with provisions and other primary necessity goods". The residents responded to the first tremor with a poorly organised evacuation, in which two schools designated as shelters in case of emergency remained partially vacant and available, which was due to the preference of most residents to stay close to their own households and spend the initial period of the rehabilitation process divided into small groups. Residents in the isolated area reported panic only during the immediate aftershocks. After the first tremor, these residents moved to the local shelter (a "retired" school) that was considered a secure location. As stated by one of the interviewees: "When the earthquake occurred, my husband and I immediately left our house, grabbing what we could, and we moved as soon as possible to the shelter, because we knew it would be safe there". This location remained a reference point during the entire recovery process due to the mutual efforts implemented by community members in organising the reconstruction of their hamlet and the restoration of its daily activities.

\section{SGD}
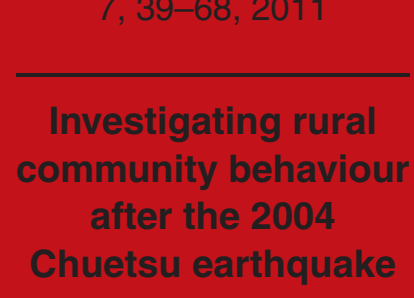

Title Page

Abstract Introduction

Conclusions References

Tables Figures

14

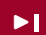

4

$>$

Back Close

Full Screen / Esc

Printer-friendly Version

Interactive Discussion 


\subsection{Community support and communication methods}

The community played an important role in the vulnerability to a natural disaster. However, the lack of preventative organisation among community members considerably reduced the efficiency of that support. In Kawaguchi, different types of community 5 behaviour were observed in each of the investigated areas. In the central area, the residents prioritised ensuring the safety of their own family and maintaining provisions for them. One of the victims stated: "After the earthquake nobody was coming, we did not have any emergency supplies, so we kept what we had for mainly ourselves, but still we tried to provide support to our neighbours". The lack of preparation for emergencies appears to have been the main issue that slowed down the recovery process. Local government support was essential for the organisation of shelters and tent camps. The arrival of rescuers provided more defined organisation as well as the reconstruction and consolidation of damaged structures and roads.

Despite its disconnection from the central area, the households in the peripheral 15 area succeeded in grouping into small units. With the interruption of local government services, the residents did not benefit from immediate support, but greater collaboration appeared among households in terms of resource sharing and mutual support. The testimony of one victim indicates the successful neighbourhood organisation that took place: "We were alone. As we had just collected the rice, we organised a kitchen in my garage together with the neighbourhood. We ate only rice and vegetables but we were all alive". Although most of the residents were organised in groups, each group considered the choice of moving in local shelters to avoid highly damaged buildings or to assist its elderly members. Individuals and groups in the isolated area took a different approach. Regardless of the lack of emergency planning, the community members rapidly organised and shared their resources extensively, enhancing their independence from the local government. As one of the interviewees reported: "We used the school kitchens to eat and the gym to sleep. We could not reach the city centre and as nobody was coming, we decided to open the road by ourselves". After

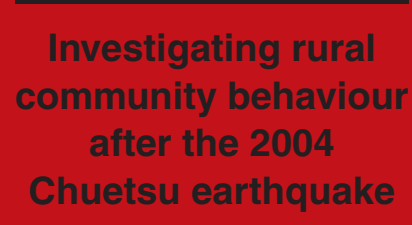

Title Page

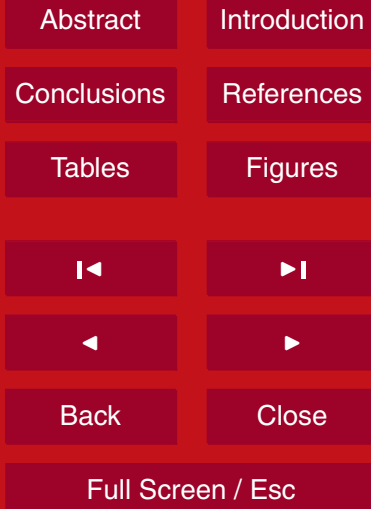

Printer-friendly Version

Interactive Discussion 
five days of isolation, local residents were able partially to reconstruct a number of local buildings and a commuting road and, thus, enabled easier access for rescuers. The greater number of elderly residents in this area necessitated additional assistance to complete the evacuation, but, despite the isolation of the area and the inaccessibility 5 of the local government services, the community members supported those needing assistance. By using only one shelter as the core of the recovery process, the residents organised more easily and overcame the lack of external support.

The inability to communicate and plan had a strong, negative impact on the rehabilitation process. As stated by a victim: "telephone and cellphone were not working, I could not even call my parents to tell them that I was safe and in good shape". It caused difficulties for individuals attempting to locate and gather members of their families, and at the community level it blocked the flow of information about rehabilitation procedures. Most respondents used their own house as the meeting point to regroup their family members. However, no effective family evacuation plans had been prepared in case of emergency. The lack of an evacuation plan was due in part to the local government not instilling sufficient awareness in or providing adequate knowledge about disaster mitigation procedures to families. Different types of communication hence appeared in each study site immediately following the earthquake, rather than there being one consistent model followed. For example, the central and peripheral areas reported more family-focused means of communication, whereas the isolated area exhibited community-oriented forms of communication with a rapid exchange of information. The latter resulted in more immediate and arguably effective support directly following the earthquake.

\section{Discussion}

25 This study investigated the behaviour of residents of Kawaguchi town after the 2004 Chuetsu earthquake. Differences in behaviour and organisation appeared in the study area and indicate the existence of clustered communities with unique characteristics according to their location in the town centre, the peripheral area or the isolated area

\section{SGD}
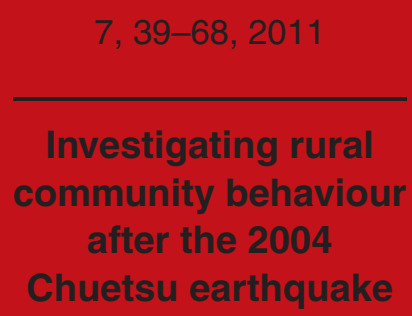

Title Page

Abstract

Introduction

Conclusions

References

Tables

Figures

14

$\Delta$

4

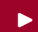

Back

Close

Full Screen / Esc

Printer-friendly Version

Interactive Discussion 
(Gismondi and Huisman, 2011). As Anderson (1994) and Cutter et al. (2008) have observed, the pre-existing patterns of daily life for community members are the main contributing factors to regional differences in organisation and behaviour, as well as vulnerability to natural disasters. Understanding these patterns could eventually inform 5 new policy response, ones that might better reinforce the structure of the community and reduce its vulnerability. Geographic location, daily relationships, social interactions and organisation explain the differences in behaviour observed among the communities within the town. These factors also have an impact in successful resource management and organisation among residents, as discussed by Blaikie et al. (1994). 10 Preparing communities to face disasters is a major policy topic around the world, including in the United States, as demonstrated by the activities and programs of the Federal Emergency Management Agency (FEMA) (FEMA, 1997).

Cultural and cognitive variables such as traditions, perceptions and sensations are among the factors limiting an individual's ability to react during a seismic event. Proper understanding of these factors may lead to improved education and use of relevant information before an event to prompt better responses if or when another event occurs (Asgary and Willis, 1997). Campaigns to warn the general public took place after the Chuetsu earthquake (Kamigaichi et al., 2009). Similar to other education campaigns worldwide, this campaign consisted of distributing informational booklets on earthquake preparedness and first aid to local schools, as well as risk awareness and preparation courses. The heterogeneity of community structures and interests always produces additional issues in successfully promoting the dissemination of information at all social and age levels inside a community. The unpredictability of natural events, such as earthquakes, means that their risk is often underestimated. In this study, it was found that residents were more aware of the risks of phenomena such as heavy snowfall and landslides often occurring during the year (Konagai, 2004). However, the occurrence of an earthquake was underestimated due to the impossibility of forecasting these phenomena (Kogan, 2007). Disaster awareness, the knowledge of longterm residents of a specific location and records of past earthquakes, is important for

\section{SGD}

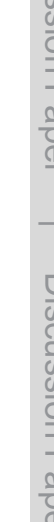

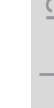

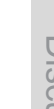

西

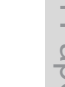

क्ष

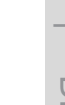


providing educational information (Tanaka, 2005). Maintaining earthquake awareness and readiness at high levels over time is a priority in different regions in Japan (Imai et al., 1997; Information Bureau of Cabinet Secretary of the Japanese Government, 1998; Tanaka and Hattori, 2001). Despite the general trend of increasing the knowl5 edge and preparation in Japan related to the emergency educational system, rural regions, such as Kawaguchi, remained partially defenceless in this respect. The absence of earthquake-resistant buildings explains the considerable amount of damage caused to infrastructure (Miranda and Bertero, 1994). Because of the high risk of residential buildings collapsing, the community played an important role in guaranteeing 10 the safety of its residents, but the observed behaviour highlights the lack of individual knowledge of emergency procedures and that this information was not provided by the local government before the earthquake.

A strong connection between age and labour type was an important factor in explaining the regional differences observed in behaviour in this study, as shown in Table 2. 15 Lower average age generations are only partially engaged in agriculture, preferring to work outside the town and the local community, and hence being less bound into local social relations that might be the basis for collective action (Spesna et al., 2009). Conversely, residents who are active in the fields rely on constant collaboration in their daily life because the work itself is based on cooperation. Thus, farming complements community activities, and the strong bonds originating in the daily life of the community overcome other issues, including the lower population density in the peripheral and isolated areas (Pretty, 1999). Because the central area has the lowest percentage of residents engaged in agricultural activities and a lower average age, the everyday connections there appear to be much weaker. Therefore, a weaker relationship at the com25 munity level is observed, where daily activities are located primarily outside the town, and family members are separated for most of the day (Lefebvre, 1970). The creation and maintenance of a community requires attention and, especially, trust and collaboration (Murray and Dunn, 1996). This phenomenon explains why neighbourhoods with a higher average age integrate better and why their members maintain stronger bonds

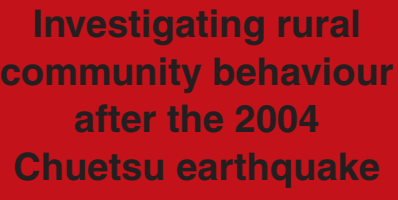

Title Page

Abstract Introduction

Conclusions References

Tables Figures

$1<$ $>1$

4

Back Close

Full Screen / Esc

Printer-friendly Version

Interactive Discussion 
by sharing the same working activity and forming a network of trust over time.

In neighbourhoods with a higher average age residents exhibit strong connections and are strongly engaged in community life. Hence, disaster planning efforts could focus on incorporating members of younger generations and newcomers to improve 5 the social network (Shaw et al., 2004). This planning has already begun to be carried out through family and community activities in a more effective way, by organising events that increase shared knowledge about the region and ensuring appropriate collaboration in case of emergency. The local government also plays an important role in supporting the subsistence of existing communities and the creation of new frastructure and providing basic emergency knowledge are examples of the types of emergency preparation needed in Kawaguchi. Raising a community's awareness of a certain topic is easier than maintaining it over time (Coburn and Spence, 2002). Therefore, the community was considered indispensable by residents in improving their safety during the recovery process. The case of the isolated area indeed highlighted the importance of the community in overcoming the damage of a seismic event through providing immediate and long-term support, sharing resources and strengthening the community's independence. The surrounding environment is associated with specific characteristics that make one community different from another. The lifestyle of the community's residents is directly responsible for how an individual relates to their family and community. There is no universal way of promoting awareness and preparation, but residents have the capacity to overcome a seismic event when they are aware of their own vulnerability (Tanaka and Hattori, 2001). The case of the isolated area illustrates how the traditional lifestyle has influenced the behaviour of its residents.

25 The two definitions of "vulnerability" and "disaster" provided in this paper are directly dependent upon the character of the human society which is living in a specific geographical area. Therefore, a disaster should not be defined only as a natural event but also consider the social interactions among members of a specific society, as a natural disaster will have a different impact according to the type of social structure

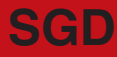

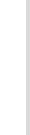

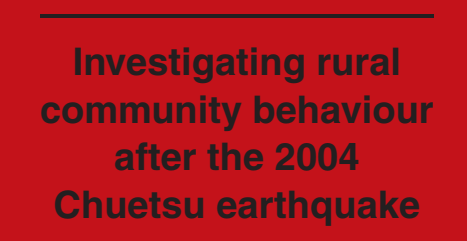

Title Page

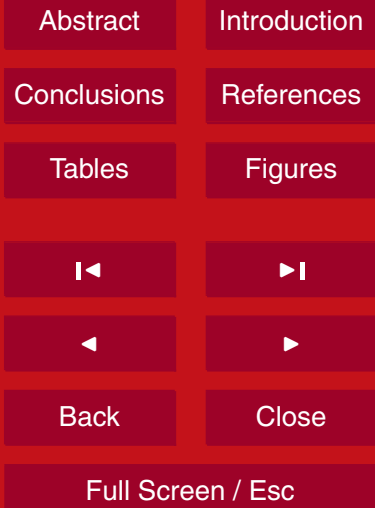

Printer-friendly Version

Interactive Discussion 
and geographical location which it encounters. To overcome the vulnerability of people resulting from a disaster, it then becomes necessary to deepen understanding of how the cultural and traditional history of a society will influence their behaviour and also which type of approach will be the most efficient to provide awareness and or5 ganisation. The differences observed in the community social organisation in the three research areas of Kawaguchi town showed that prior approaches used to disseminate knowledge and organise local communities had been insufficient. Furthermore, the concept of vulnerability assumes different meanings according to the characteristics of residents and which institutional level is considered (ADPC, 2003 and Triulzi et al.,

2003). At national level, the vulnerability depends on the long-term strategies in loss reduction, mitigation and an effective dialogue between government and citizens. At community level, the vulnerability of any one single household potentially contributes to increasing the whole community vulnerability. However, existing social and cultural structures within the community are the main determinants of the resilience of the com15 munity to the disaster (ADPC, 2003).

This paper therefore wants to stress the importance of reducing the community level vulnerability. As a concrete example, in this study three specific study areas were indeed selected. In the central area, the vulnerability was the highest among study areas, mainly due to the lack of deep social relations and what can be portrayed as a weaker social structure that slowed down the rehabilitation process and the interaction between residents, who opted for an individualistic behavioural response to the crisis. In the case of the peripheral area, the distance between households and the impossibility of communicating with the city hall were the main factors explaining the residents' vulnerability. However, the presence of a more traditional and collective lifestyle reduced the residents' vulnerability, as they could more easily overcome the isolation period using local hierarchical social relations to their advantage. The isolated are,a thanks to the strong social relations and a well defined structure of the society, could better overcome the isolation period and therefore better attend to the rehabilitation process. The community successfully managed to be independent, especially during

\section{SGD}

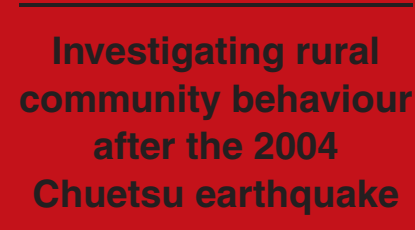

Title Page

Abstract

Introduction

Conclusions

References

Tables

Figures

14

$\rightarrow$

4

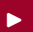

Back

Close

Full Screen / Esc

Printer-friendly Version

Interactive Discussion 
the isolation period, in a sense thereby overcoming their vulnerability, yet the fact that they were obliged to be on their own for such long time was itself an issue. Therefore, rather than vulnerability in the isolated areas, it would be more appropriate to speak about inaccessibility due to the five days of isolation. This paper follows the concepts 5 of rural and urban introduced by Kagitçibasi (1997), Kashima (2001) and Oyserman et al. (2002). These concepts are adopted in this paper to clarify the distinction in the residents' behaviour. A certain danger of essentialising the concepts of urban in contrast with rural must be acknowledged as restrictive and posing certain constraints to the conclusions being drawn as outputs from this paper. Further studies should be done in 10 order to deepen the investigation of community behaviour investigation in rural areas and perhaps to move beyond the concepts described in this paper.

From the above assumptions, it is believed that a community-driven plan taking into account the specific characteristics of each community, and created by the community itself with the support of local government, could more effectively raise awareness 15 among residents about where they are living, the actual threats of natural disasters and ways to prepare for and overcome them. The Japanese family and rural community hierarchical system could be used more effectively to guarantee faster response, better organisation and greater security, especially in the earliest stage of the recovery process, as also stated by Shaw et al. (2004). In this stage, the rapidity of action is essential, as was seen in the isolated area in this study. Division into small, well-organised groups proved to be particularly effective after the earthquake, ensuring the welfare of residents. The difference in social relations and hierarchical structures present in each community is believed to be the focal point in this study as representing the "hearth" of the community itself. The results of this study therefore recommend using the social activities and the underlying social structures and relations of the local Japanese communities to promote awareness about the main risks arising within a specific area. Producing a sufficient degree of awareness could eventually lead to increased independence and organisation for communities, further enhancing a cultural feature typical of Japan: preparation in the face of unexpected disasters.

\section{SGD}
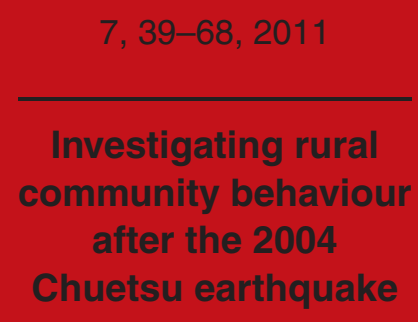

Title Page

Abstract

Introduction

Conclusions

References

Tables

Figures

14

$\Delta$

4

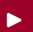

Back

Close

Full Screen / Esc

Printer-friendly Version

Interactive Discussion 
Acknowledgements. The author would like to thank the editor and reviewers for their thoughtful comments and support during the reviewing process.

\section{References}

Asian Disaster Preparedness Center (ADPC): Earthquake Vulnerability Reduction for Cities, in: Third Regional Training Course on Earthquake Vulnerability Reduction for Cities, Bangladesh, 1-10, 2003.

Adger, W. N.: Vulnerability, Global Environ. Change, 16, 268-281, 2006.

Alexander, D.: Death and Injury in Earthquakes, Disasters, 9, 57-60, 1985.

Anderson, K. M. and Manuel, G.: Gender Differences in Reported Stress Response to the Loma Prieta Earthquake, Sex Roles, 30, 725-733, 1994.

Anderson, M. and Woodrow, P.: Rising from the Ashes: Development Strategies in Time of Disaster, Boulder, CO and London, IT Publications and Lynne Rienner, 1998.

Asgary, A. and Willis, K. G.: Household behavior in response to earthquake risk, Disasters, 21, 354-365, 1997.

15 Baumeister, R. F.: Identity: Cultural change and the struggle for self, New York, Oxford University Press, 1986.

Baumeister, R. F.: How the self became a problem: A psycho-logical review of historical research, J. Pers. Soc. Psychol., 52, 163-176, 1987.

Blaikie, P., Cannon, T., Davis, I., and Wisner, B.: At Risk: Natural Hazards, People's Vulnerability, and Disasters, Routledge, London, 1994.

Burton, I., Kates, R. W., and White, G. F.: The Environment as Hazard, The guilford Press, New York, 1993.

Coburn, A. and Spence, R.: Earthquake Protection (Second Edn.), Wiley Eds., 2002.

Cuny, F.: Disasters and Development, New York, Oxfam and Oxford University Press, 1983.

Cutter, S. L., Barnes, L., Berry, M., Burton, C., Evans, E., Tate, E., and Webb, J.: A place-based model for understanding community resilience to natural disasters, Global Environ. Change, 18, 598-606, 2008.

Dynes, R. R.: Disaster Reduction: The importance of adequate assumptions about social organisation, Sociol. Spectrum, 6, 24-25, 1993.
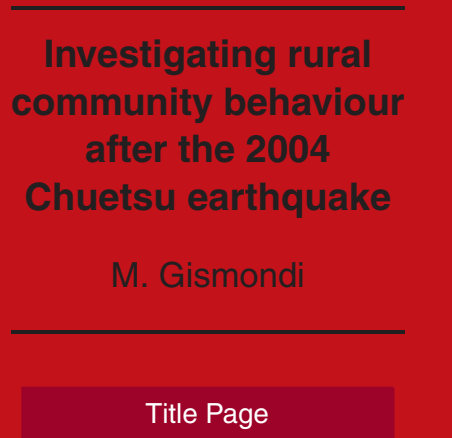
EMC (Emergency Maping Center): Emergency Maping Center Report, 2007 Niigata-Ken Chuetsu-oki Earthquake, Emergency Mapping Center GK Kyoto, 2007.

ESRI (Economic and Social Research Institute): GIS for Earthquakes, GIS Best Practice, available at: www.esri.com/publicsafety, February 2007.

5 FEMA (Federal Emergency Management Agency): Multihazard Identification and Risk Assessment: A Cornerstone of the National Mitigation Strategy, Federal Emergency Management Agency, Washington DC, 1997.

FEMA (Federal Emergency Management Agency): Earthquake loss estimation methodology, HAZUS99, Service release 2, technical manual, Federal Emergency Management Agency,

10 Washington DC, 2001.

FEMA (Federal Emergency Management Agency): Protecting your Property from Earthquakes, Federal Emergency Management Agency, Washington DC, 2006.

Fritz, C. E.: Disasters, in: Contemporary social problems, edited by: Merton, R. K. and Nisbet, R. A., New York, Harcourt, 651-694, 1961.

15 Gee, M.: Japanese town with few children offers glimpse of future, Globe and Mail, A1-A11, 2000.

Gismondi, M.: Spatial analysis of the behaviour of residents after the 2004 Chuetsu Earthquake: a case study of Kawaguchi Village, Japan, in: Proceedings of The Praire Summit, Canadian Association of Geographers Annual Meeting, 129-132, 2010.

20 Gismondi, M. and Huisman O.: Spatio-temporal behaviour after an earthquake. A case study of Kawaguchi town, Japan, Disaster Prevention and Management, in press, 2011.

Glenn, C. M.: Natural Disasters and Human Behavior, Psychology: A Journal of Human Behavior, 16, 23-36, 1979.

Hewitt, K.: Interpretations of Calamity: From the Viewpoint of Human Ecology, Allen and Unwin, London, 1983.

Hirata, N., Sato, H., Sakai, S., Kato, A., and Kurashimo, E.: Fault system of the 2004 Mid Niigata Prefecture Earthquake and its aftershocks, Landslides, 2, 153-157, 2005.

Imai, N., Nakamura, K., and Tada, I.: Influence and changes of dwelling life and residential consciousness concerning life style by Hanshin-Awaji earthquake: Case study of residents living in apartments of housing and urban development corporation in Nara and Hamamatsu (Research on conditions of dwelling life and residential consciousness considering a disaster prevention (Part I)), Kaseigaku Kenkyu (Studies on Home Economics), 43, 60-66, 1997 (in Japanese with English abstract).
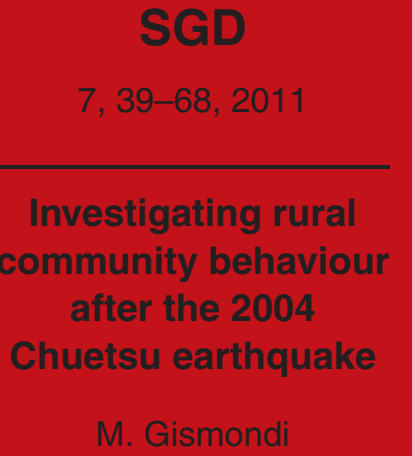

Title Page

Abstract Introduction

Conclusions References

Tables Figures

14

$\Delta$

4

Back Close

Full Screen / Esc

Printer-friendly Version

Interactive Discussion 
Information Bureau of Cabinet Secretary of the Japanese Government: Public-opinion survey on disaster prevention, Tokyo, Prime Minister's Office, Tokyo, 1998 (in Japanese).

loakimides, G., Carydis, G., Pnayotis, G., and Elias, D.: Earthquake preparedness and local government, Proceedings of the Seminar on Earthquake Preparedness, Athens, 127-139, 51984.

Kamigaichi, O., Saito, M., Doi, K., Matsumori, T., Tsukada, S., Takeda, K., Shimoyama, T., Nakamura, K., Kiyomoto, M., and Watanabe, Y.: Earthquake Early Warning in Japan: Warning the General Public and Future Prospects, Seismol. Res. Lett., 80, 717-726, 2009.

Kagan, Y. Y.: Are earthquakes predictable?, Geographical Journal International, 131, 505-525, 1997.

Kagitçibasi, C.: Individualism and collectivism, in: Handbook of cross-cultural psy-chology, edited by: Berry, J. W., Poortinga, Y. H., and Pandey, J., Boston, 1, 43-83, 1997.

Kashima, Y.: Culture and social cognition: Towards a social cognition of cultural dynamics, in: Handbook of culture and psychology, edited by: Matsumoto, D., Oxford University Press, 15 325-360, 2001.

Kimura, R., Hayashi, H., Tatsuki, S., and Urata, Y.: Clarifying the Human Behavior of the Disaster Victims after the Great Hanshin-Awaji Earthquake, Journal of Social Safety Science, 1, 93-102, 1999 (Japanese).

Kimura, R., Hayashi, H., Tatsuki, S., and Tamura, K.: Determinants and Timing of Housing Reconstruction in the 1995 Hanshin-Awaji Earthquake Disaster, A 2001 Replication, Journal of Social Safety Science, 3, 23-32, 2001 (Japanese).

Kimura, R., Hayashi, H., and Tamura, K.: Which Roles are Citizens and the Community to Play in the Field of Disaster Management? (Results from the Random Sampled Social Surveys to the Disaster Victims of the 1995 Kobe Earthquake and the 2004 Niigata Earthquake Disaster), 2nd International Conference on Urban Disaster Reduction, Taipei, 2007.

King, S. A. and Kiremidjan, A.: Regional seismic hazard and risk analysis through geographic information systems, BLUME-111, The John A. Blume Earthquake Engineering Center Stanford, California, US, 1994.

Konagai, K.: Preliminary Report, Mid-Niigata Prefecture Earthquake Preliminary report on damage caused by the Mid-Niigata Prefecture Earthquake on October 23, 2004.

Lefebvre, H.: From rural to urban, Annthropos, Paris, 1970.

Lynch, K.: The image of the city, The Massachusetts Institute of Technology Press, US, 1960.

Matsushita, K., Fujii, M., and Takata, T.: Damage of Houses and Residential Areas by Niigata

\section{SGD}
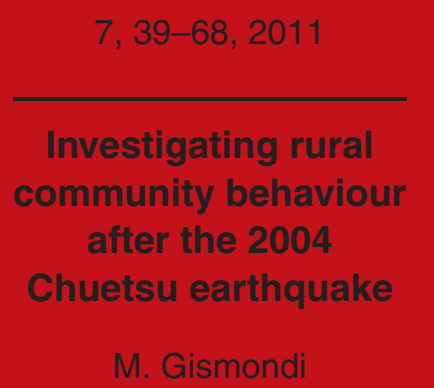

Title Page

Abstract

Introduction

Conclusions

References

Tables Figures

14

DI

4

Back

Close

Full Screen / Esc

Printer-friendly Version

Interactive Discussion 
Prefecture Earthquakes (Part 1), in: Proceedings of the Eighteenth International Offshore and Polar Engineering Conference, Vancouver, 2008.

Mansoirian, A., Rajabifard, A., and Zoej, M. J. V.: SDI conceptual modelling for disaster management, ISPRS Workshop on Service and Application of Spatial Data Infrastructure, XXXVI, 5 Hangzhou, China, 2005.

Miranda, E. and Bertero, V. V.: Evaluation of Strenght Reduction Factors for EarthquakeResistant Design, Earthq. Spectra, 10, 357-379, 1994.

Munich, R.: Topics Geo annual review: natural catastrophes 2004, Munich Reinsurance Company, Germany, 2005.

10 Murray, M. and Dunn, L.: Revitalizing rural America: a perspective on collaboration and community, John Wiley \& Sons, UK, 1996.

OECD (Organisation for Economic Co-operation and development): OECD Reviews of Risk Management Policies. Japan: Large-scale Floods and Earthquakes, OECD Publications, France, 2009.

Oyserman, D., Coon, H. M., and Kemmelmeier, M.: How American is individualism? Relational Americans and other lessons from cultural and cross-cultural research, Psychol. Bull., 128, 3-72, 2002.

Olshansky, R. B., Nakabayashi, I., and Ohnish, K.: Socioeconomic, Polocy, and Planning Aspects of the 2004 Niigata Ken Chuetsu Earthquake, Earthq. Spectra, 22, 1-22, 2006.

20 Pretty, J.: The Living Land: "Agriculture, Food and Community Regeneration in the 21st Century", Earthscan, UK, 1999.

Research Group on Damage of Mid-Niigata Earthquake: The Mid Niigata Prefecture Earthquake in 2004. Relation of earthquake damage with geomorphic and geologic setting, Association for the Geological Collaboration in Japan, Tokyo, 2005 (in Japanese).

Saadatseresht, M. and Mansuorian, A.: Preplanning for temporal settlement of victims in disasters, MapAsia 2006, Thailand, 2006.

Shaw, R., Shiwaku, K., Kobayashi, H., and Kobayashi, M.: Linking experience, education, perception and earthquake preparedness, Disaster Prevention and Management, 13, 3949, 2004.

30 Smith, K. J. and Belgrave, L. L.: Collective Behavior: after Hurricane Andrew, in: Down to Earth Sociology, edited by: Henslin, J., Free Press, New York, 2003.

Smith, R. J.: The Japanese Rural Community: Norms, Sanctions, and Ostracism, Am. Anthropol., 63, 522-533, 1961.

\section{SGD}
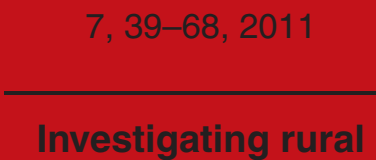

community behaviour after the 2004

Chuetsu earthquake

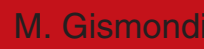

Title Page

Abstract Introduction

Conclusions References

Tables Figures

14

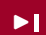

4

Back

Full Screen / Esc

Printer-friendly Version

Interactive Discussion 
Spesna, D., Pospech, P., Nohel, F., Drlik, J., and Delin, M.: Aging of the agricultural workforce in relation to the agricultural labour market, Agricultural Economy, 55, 424-535, 2009.

Suganuma, K.: Recent Trends in Earthquake Disaster Management in Japan, Quarterly Review of the Science and Technology Foresight Center, Tokyo, 2006.

5 Tanaka, K.: The impact of disaster education on public preparation and mitigation for earthquakes: a cross-country comparison between Fukui, Japan and the San Francisco Bay Area, California, US, Appl. Geogr., 25, 201-225, 2005.

Tanaka, K. and Hattori, I.: Analysis of disaster-measures based on survey of people's consciousness of earthquake disaster prevention in the Fukui area, central Japan, Nature and Environment of the Sea of Japan Districts, 8, 79-102, 2001 (in Japanese with English abstract).

Tierney, K. J., Lindell, M. K., and Perry, R. W.: Facing the Unexpected: Disaster Preparedness and Response in the United States, Joseph Henry Press, US, 2001.

Triandis, H. C.: Individualism and Collectivism, Boulder, CO, Westview, 1995.

15 Triulzi, U., Tommasoli, M., and Montalbano, P.: Policy Options for Socioeconimic Vulnerability Analysis: conflict analysis and long-term development programmes and strategies, FAO international workshop on "Food Security in Complex Emergencies: building policy frameworks to address longer-term programming challenges", Italy, 1-12, 2003.

Tucker, B., Trumbull, G., and Wyss, S.: Some Remarks Concerning Worldwide Urban Earth20 quake Hazard and Earthquake Hazard Mitigation, in: Issues in Urban Earthquake Risk, Kluwer Academic Publishers, Netherlands, 1994.

Turner, R. H.: Earthquake prediction and public policy: Disillusions from a National Academy of Sciences report, Mass Emergencies, 1, 179-202, 1976.

United Nations Centre for Regional Development (UNCRD): Global Earthquake Safety Initiative (GESI) Pilot Project (Final Report), GeoHazard International United Nations Centre for Regional Development, 2001.

United States Geological Survey (USGS): Putting Down Roots in Earthquake Country, United States Government Printing Office, US Geological Survey General Information Product 15, 2005.

so Usami, T.: Study of Historical Earthquakes in Japan, B. Earthq. Res. I. Tokyo, 54, 399-439, 1979.

Yoshida, T.: Social Conflict and Cohesion in Japanese Rural Community, Ethnology, 3, 219231, 1964.

Investigating rural

community behaviour after the 2004

Chuetsu earthquake

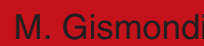

Title Page

Abstract Introduction

Conclusions References

Tables Figures

14

$\Delta$

4

Back Close

Full Screen / Esc

Printer-friendly Version

Interactive Discussion 
Wisner, B.: The communities Do Science! Proactive and Contextual Assessment of Capability and Vulnerability in the Face of Hazards, in: Vulnerability: Disasters, Development and People, ch. 13., edited by: Bankoff, G., Frerks, G., and Hilhorst, T., London, Earthscan, UK, 2003.

5 Wisner, B., Blaikie, P., Cannon, T., and Davis, I.: At Risk (second edn.), Natural hazards, people's vulnerability and disasters, Routledge Taylor and Francis Group, New York, US, 2004.

World Health Organisation (WHO): Earthquakes and People's Healths, in: Proceedings of the WHO Symposium, Kobe, 27-30 January, Kobe, Japan: WHO Centre of Health Development, 1997.

World Health Organisation (WHO): Community emergency preparedness: a manual for managers and policy-makers, World Health Organisation, Geneva, Switzerland, 1999.

SGD

7, 39-68, 2011

\section{Investigating rural}

community behaviour after the 2004

\section{Chuetsu earthquake}

M. Gismondi

Title Page

Abstract

Introduction

Conclusions

References

Tables

Figures

14

$>1$

4

Back

Close

Full Screen / Esc

Printer-friendly Version

Interactive Discussion 
Table 1. Main topics of discussion during the interviews.

\begin{tabular}{l}
\hline Damage received \\
\hline - House damage \\
- Injuries within the household \\
- Other structural damages \\
\hline Evacuation methods \\
\hline - First reactions during the earthquake \\
- Reason of the first reactions \\
- Provisional shelter choice and reason \\
\hline Shelter knowledge \\
\hline
\end{tabular}

- Support provided

- Auto-evaluation of the behaviour

- Support received

- Residents requiring assistance

Community lifestyle

- Activities

- Social relations

- Social structures

Spatio-temporal behaviour, discussed in Gismondi and Huisman (2011)

- Spatial mapping

- Position of family members over time

SGD

7, 39-68, 2011

Investigating rural

community behaviour

after the 2004

Chuetsu earthquake

M. Gismondi

Title Page

Abstract

Conclusions

Tables

14

4

Back

Full Screen / Esc

Printer-friendly Version

Interactive Discussion 
Table 2. Relevant attributes in the three research areas. Data source: population census (2000); agricultural census (2000); Kawaguchi town local governmental office (2000).

\begin{tabular}{lrrr}
\hline & Central & Peripheral & Isolated \\
\hline Number of residents & 1403 & 322 & 138 \\
Number of households & 432 & 80 & 52 \\
Average number of residents per house & 3.2 & 4 & 2.6 \\
Number of residents engaged in farming & 134 & 173 & 116 \\
Number of households engaged in farming & 29 & 39 & 35 \\
Number of communities & 6 & 2 & 1 \\
Average age & 45 & 57 & 64 \\
Number of annual activities & 8 & 3 & 6 \\
Time isolated (number of days) & 3 & 3 & 5 \\
Distance from the city Centre (in km) & $0-0.5$ & $1-2$ & $8-8.5$ \\
\hline
\end{tabular}

SGD

7, 39-68, 2011

Investigating rural

community behaviour

after the 2004

Chuetsu earthquake

M. Gismondi

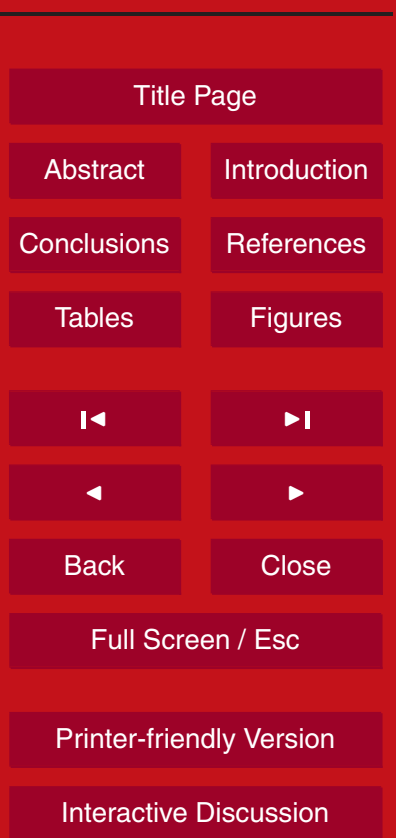




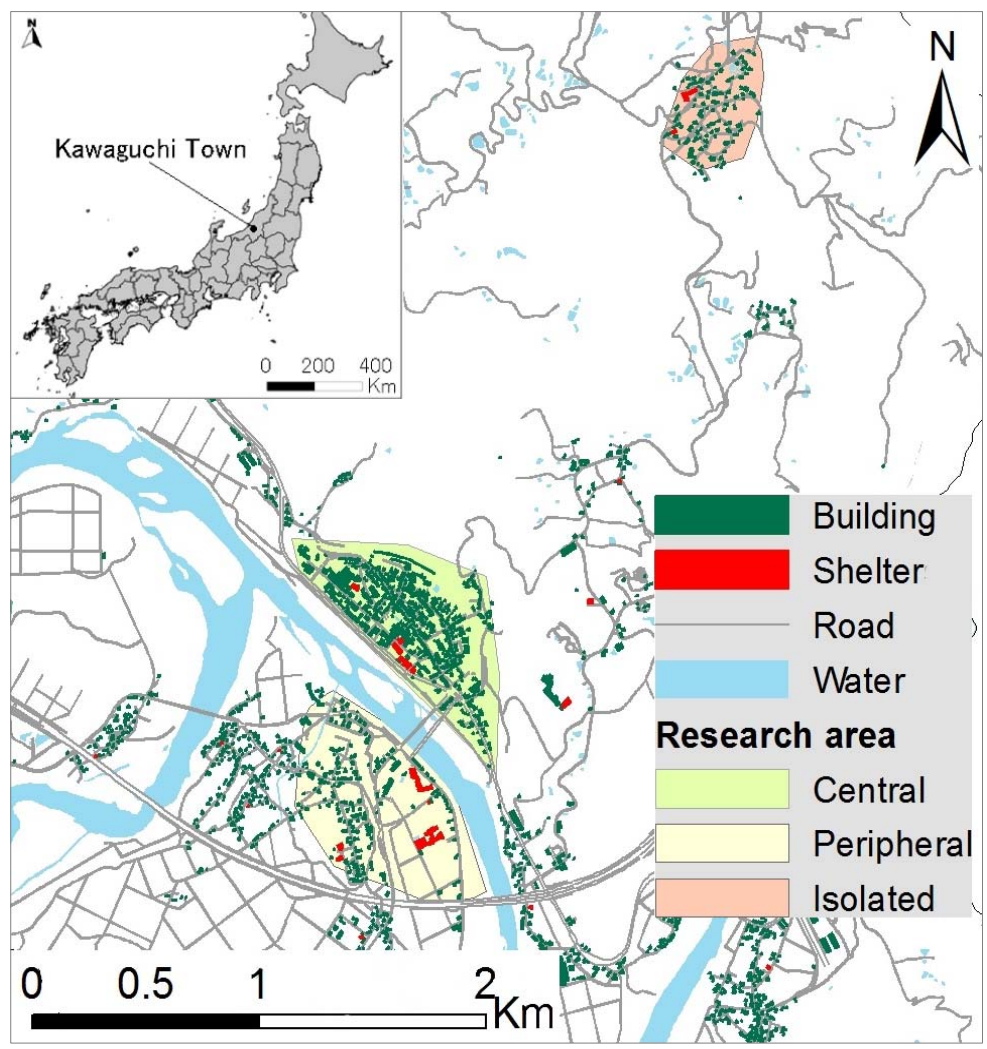

\section{SGD}

7, 39-68, 2011

\section{Investigating rural}

community behaviour

after the 2004

Chuetsu earthquake

M. Gismondi

Title Page

Abstract

Introduction

Conclusions

References

Tables

Figures

14

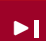

4

Back

Close

Full Screen / Esc

Fig. 1. The three research areas within Kawaguchi town.

Printer-friendly Version

Interactive Discussion

(c) $\underset{\mathrm{Br}}{(1)}$ 


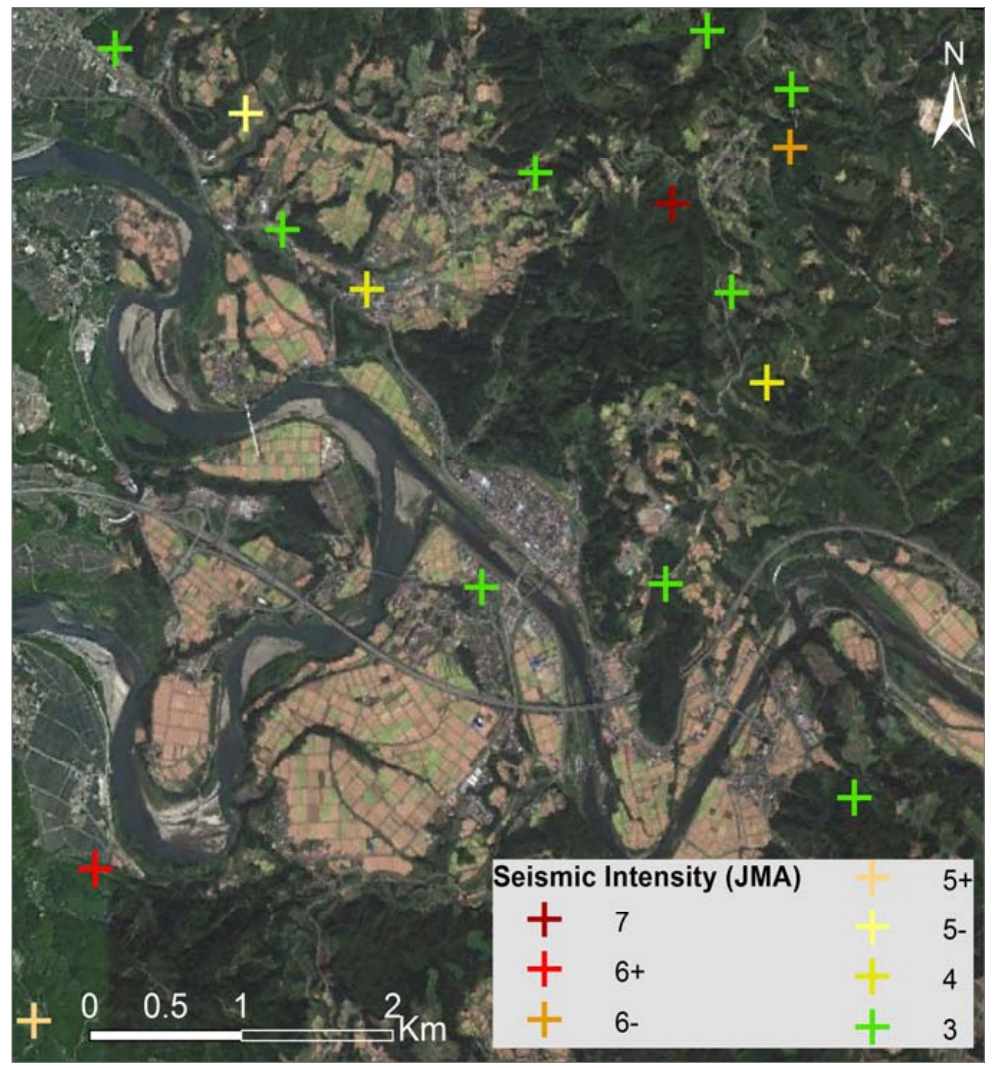

\section{SGD}

7, 39-68, 2011

Investigating rural

community behaviour after the 2004

Chuetsu earthquake

M. Gismondi

Title Page

Abstract

Introduction

Conclusions

References

Tables

Figures

14

$\rightarrow$

4

Back

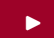

Full Screen / Esc

Fig. 2. Location of the main earthquakes in proximity to Kawaguchi town. Data source: Niigata Chuetsu Earthquake GIS project website.

Printer-friendly Version

Interactive Discussion

(c) (i) 
a)

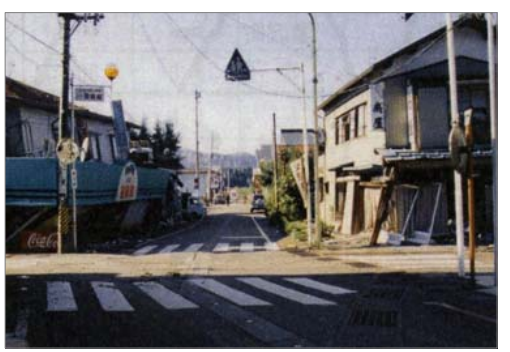

After the earthquake

Tamujiyama section (Isolated hamlet)

c)

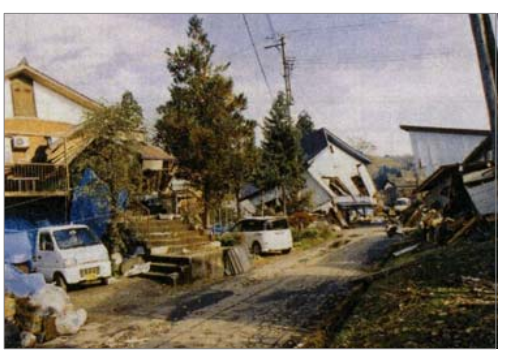

After the earthquake b)

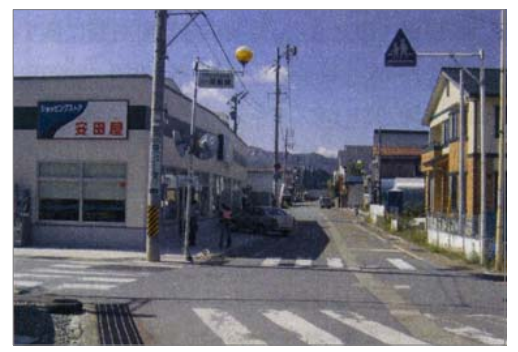

At the end of the restoration process

d)

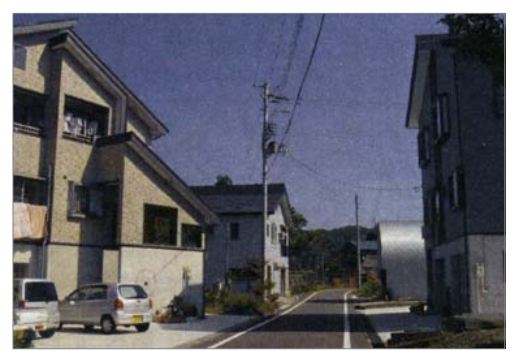

At the end of the restoration process
SGD

7, 39-68, 2011

Investigating rural

community behaviour after the 2004

Chuetsu earthquake

M. Gismondi

Title Page

Abstract

Introduction

Conclusions

References

Tables

Figures

14

DI

\section{4}

Back

Close

Full Screen / Esc

Printer-friendly Version

Interactive Discussion

(c) (i)

Fig. 3. The structural damage provoked by the Chuetsu earthquake. Data source: Niigata Prefecture, Kawaguchi town city office. Note: photos were taken by an officer of Kawaguchi town a week after the Chuetsu earthquake occurred and after the reconstruction was completed (Summer, 2005). 